\title{
Pengaruh Variabel Makroekonomi Terhadap Jumlah Penerimaan Zakat di Badan Amil Zakat Nasional (Baznas) Pusat Tahun 2012 - 2016
}

\author{
Arif Afendi \\ arifafendi@walisongo.ac.id \\ Universitas Islam Negeri Walisongo Semarang, Indonesia \\ Masuk: 20 Maret 2018; Diterima: 12 Juni 2018; Terbit: 25 Juni 2018
}

\begin{abstract}
The purpose of this research is to examine the impact of macroeconomic factor includes inflation, rupiah exchange rate and gold price to the total amount of collected zakat in amil zakat nasional agency (Baznas). This research is a quantitative by using secondary data. The data used from Baznas, Bank of Indonesia and Bloomberg from 2012 until 2016. The data were analyzed by using multiple linear regressions. The result of the research shows that the inflation has negative and significant influence. It means, inflation increase caused the price of goods be rise and people reduced to pay zakat so total collected zakat will be less. Rupiah exchange rate has positive and significant influence, it's mean, dollar increased to rupiah made people who had income in dollars will be rich and they will pay zakat so total collected zakat will be rise. While the gold price has negative influence, it's mean, the rise in gold priced is usually influenced by increasing of inflation so the price of goods will be rise, to people who has fixed income will use their money to something usefull so total collected zakat will be less.
\end{abstract}

Keywords: Total collected zakat; inflation; rupiah exchange rate; gold price

\begin{abstract}
Abstrak
Tujuan dari penelitian ini adalah untuk menguji dampak faktor makroekonomi termasuk inflasi, nilai tukar rupiah dan harga emas terhadap total jumlah zakat yang dikumpulkan di lembaga amil zakat nasional (Baznas). Penelitian ini bersifat kuantitatif dengan menggunakan data sekunder. Data yang digunakan dari Baznas, Bank Indonesia dan Bloomberg dari tahun 2012 hingga 2016. Data dianalisis dengan menggunakan regresi linier berganda. Hasil penelitian menunjukkan bahwa inflasi memiliki pengaruh negatif dan signifikan. Artinya, kenaikan inflasi menyebabkan harga barang naik dan orang dikurangi untuk membayar zakat sehingga total zakat yang dikumpulkan akan berkurang. Nilai tukar rupiah memiliki pengaruh positif dan signifikan, artinya, dolar meningkat menjadi rupiah membuat orang yang memiliki pendapatan dalam dolar akan menjadi kaya dan mereka akan membayar zakat sehingga jumlah zakat yang dikumpulkan akan meningkat. Sementara harga emas memiliki pengaruh negatif, itu berarti, kenaikan harga emas biasanya dipengaruhi oleh peningkatan inflasi sehingga harga barang akan naik, untuk orang yang memiliki pendapatan tetap akan menggunakan uang mereka untuk sesuatu yang bermanfaat sehingga total zakat yang dikumpulkan akan berkurang.
\end{abstract}

Kata Kunci: Jumlah penerimaan zakat; inflasi; kurs; harga emas 


\section{PENDAHULUAN}

Salah satu permasalahan yang dialami oleh Indonesia sejak dahulu adalah tingginya angka kemiskinan. Sejak tahun 1990 hingga saat ini permasalahan kemiskinan sangat dipengaruhi oleh kondisi perekonomian, salah satunya adalah faktor makroekonomi yang memburuk sehingga mengakibatkan krisis ekonomi. Krisis ekonomi yang melanda Indonesia pada tahun 1998 diawali dengan terjadinya krisis moneter yang berdampak pada menurunnya kepercayaan internasional terhadap Indonesia. Dampak lain dari terjadinya krisis 1998 adalah melemahnya nilai tukar rupiah terhadap dolar serta terjadinya inflasi yang tinggi. Hal ini menyebabkan semakin melemahnya daya beli masyarakat karena saat itu harga barang banyak yang naik tak terkendali dan biaya hidup semakin tinggi. Berdasarkan data Bank Indonesia, pada bulan Juni 1998 nilai tukar rupiah terhadap dolar semakin melemah dengan inflasi mencapai 45,4\%. Kondisi ini menyebabkan persentase penduduk miskin bertambah. Laju Inflasi yang mencapai 45,4\% jelas akan menurunkan kualitas hidup masyarakat, dimana pengeluaran terbesar mereka hanya digunakan untuk kebutuhan konsumsi. Hal ini menunjukkan melonjaknya harga barang yang disebabkan oleh inflasi akan membuat masyarakat jatuh miskin (www.bi.go.id).

Menurut Putong (2002), Inflasi dapat terjadi karena dua hal, yaitu tarikan permintaan (Demand Pull Inflation) dan inflasi dorongan biaya (Cost Push Inflation). Inflasi tarikan permintaan (Demand Pull Inflation) terjadi karena adanya permintaan total yang berlebihan dimana biasanya disebabkan oleh meningkatnya likuiditas di pasar sehingga terjadi permintaan yang tinggi dan mengakibatkan perubahan pada tingkat harga. Bertambahnya volume alat tukar atau likuiditas yang terkait dengan permintaan terhadap barang dan jasa mengakibatkan bertambahnya permintaan terhadap faktor-faktor produksi tersebut. Meningkatnya permintaan terhadap faktor produksi itu kemudian menyebabkan harga faktor produksi meningkat. Jadi, inflasi ini terjadi karena suatu kenaikan dalam permintaan total sewaktu perekonomian yang bersangkutan dalam situasi full employment dimana biasanya lebih disebabkan oleh rangsangan volume likuiditas di pasar yang berlebihan. Meningkatnya likuiditas di pasar juga disebabkan oleh banyak faktor selain yang utama tentunya kemampuan bank sentral dalam mengatur peredaran jumlah uang, kebijakan suku bunga bank sentral, sampai dengan aksi spekulasi yang terjadi di sektor industri keuangan.

Sedangkan Inflasi dorongan biaya (Cost Push Inflation) dapat terjadi akibat adanya kelangkaan produksi dan atau adanya kelangkaan distribusi, walaupun permintaan secara umum tidak ada perubahan yang meningkat secara signifikan. Adanya ketidaklancaran aliran distribusi ini atau berkurangnya produksi yang tersedia dari rata-rata permintaan normal dapat memicu kenaikan harga sesuai dengan berlakunya hukum permintaanpenawaran, atau juga karena terbentuknya posisi nilai keekonomian yang baru terhadap produk tersebut akibat pola atau skala distribusi yang baru.

Selanjutnya, yang mempengaruhi jumlah penerimaan zakat di suatu negara adalah Kurs atau nilai tukar. Pergerakan nilai tukar rupiah terhadap mata uang asing khususnya dolar Amerika setelah diterapkannya kebijakan sistem nilai tukar mengambang bebas di Indonesia pada tanggal 14 Agustus 1998, telah membawa dampak dalam perkembangan perekonomian nasional baik dalam sektor moneter maupun sektor riil. Depresiasi nilai tukar rupiah terhadap dolar Amerika menjadi sangat besar pada awal penerapan sistem tersebut sehingga meningkatkan ketidakpastian di sektor bisnis dan ekonomi di 
Indonesia (Abimanyu, 2004). Menurut Mankiw (2007), nilai tukar mata uang antara dua negara adalah harga dari mata uang yang digunakan oleh penduduk negara-negara tersebut untuk saling melakukan perdagangan antara satu sama lain. Sedangkan Fabozzi dan Alberto (1996) mendefinisikan nilai tukar mata uang sebagai jumlah dari mata uang suatu negara yang dapat ditukarkan per unit mata uang negara lain, atau dengan kata lain harga dari satu mata uang terhadap mata uang lain.

Abimanyu (2004) menyatakan bahwa nilai tukar mata uang adalah harga mata uang relatif terhadap mata uang negara lain, dan oleh karena nilai tukar ini mencakup dua mata uang, maka titik keseimbangannya ditentukan oleh penawaran dan permintaan dari kedua mata uang. Dengan demikian, dapat disimpulkan bahwa nilai tukar mata uang adalah harga dari mata uang suatu negara terhadap mata uang negara lain yang dipergunakan dalam melakukan perdagangan antara kedua negara tersebut dimana nilainya ditentukan oleh penawaran dan permintaan dari kedua mata uang. Dengan perubahan kondisi ekonomi serta sosial politik yang terjadi di suatu negara, nilai tukar mata uang suatu negara terhadap mata uang negara lainnya dapat berubah secara substansial. Mata uang suatu negara dikatakan mengalami apresiasi jika nilai tukarnya terhadap mata uang negara lain relatif mengalami kenaikan. Sebaliknya, mata uang suatu negara dikatakan mengalami depresiasi jika nilai tukarnya terhadap mata uang negara lain relatif mengalami penurunan.

Dalam kondisi tertentu, kenaikan dan penurunan nilai tukar mata uang terjadi atas intervensi pemerintah, dalam hal ini kebijakan bank sentral dalam menaikkan dan menurunkan nilai tukar mata uang domestik untuk menyesuaikannya dengan nilai tukar mata uang yang sebenarnya di pasar. Menurunnya daya beli masyarakat tidak hanya berdampak pada menurunnya kualitas hidup dalam memenuhi kebutuhan pokok seharihari, namun juga berpengaruh terhadap kegiatan-kegiatan keagaamaan. Salah satu contoh praktek keagamaan yang wajib dan dikenal dalam kehidupan masyarakat adalah kewajiban membayar zakat. Ketika masyarakat lebih mementingkan untuk memenuhi kebutuhan pokoknya terlebih dahulu, dikarenakan inflasi yang sangat tinggi, harga barang-barang menjadi sangat mahal sehingga mengakibatkan penghasilan masyarakat banyak tersedot untuk pemenuhan kebutuhan pokok. Hal ini mengakibatkan orang yang tadinya mampu untuk membayar zakat, menjadi orang yang tidak mampu membayar zakat. Bahkan, sebagain besar masyarakat menjadi orang yang berhak menerima zakat (Bariadi, Zen, \& Hudri, 2005).

Selanjutnya, yang mempengaruhi jumlah penerimaan zakat di suatu negara adalah harga emas. Emas adalah sejenis logam mulia terpercaya yang bisa mempertahankan nilainya dan digunakan dalam transaksi. Emas mempunyai sifat yang unik dan langka karena emas terbuat dari proses magmatis atau pengkonsentrasian di permukaan bumi. Emas merupakan logam yang bersifat lunak dan tidak mudah berkarat sehingga dalam perkembangannya emas dapat dibentuk menjadi perhiasan. Emas sudah dikenal sebelum masehi dan digunakan sebagai alat untuk bertransaksi. Saat ini, emas menjadi salah satu investasi atau pemberi devisa terbesar bagi negara (Oei, 2009).

Dalam hal harga, emas mengenal harga spot dan harga future. Harga spot merupakan harga dasar fisik yang berubah setiap saat mengikuti perkembangan harga komoditas yang diperdagangkan saat ini. Sedangkan definisi mengenai harga future menurut Alexander, Sharpe, dan Bailey (2000) "future price is the buying price and it is written 
on future contract”. Kedua harga tersebut saling mengisi satu sama lain atau dengan kata lain berhubungan positif karena biasanya para investor dalam menentukan harga di pasar fisik menggunakan harga future. Sebaliknya, apabila investor ingin menanamkan modal di pasar future, mereka biasanya mengambil acuan harga dari pasar fisik yakni harga spot. Kenaikan harga emas dalam dolar Amerika akan menyebabkan naiknya nilai nisab dalam rupiah. Hal ini tentunya berlaku bagi orang-orang yang menyimpan emas dalam harta kekayaannya. Meningkatnya harga emas akan meningkatkan penghasilan mereka dalam rupiah. Akibatnya, jumlah zakat yang harus dikeluarkan akan lebih besar dan pada akhirnya jumlah zakat yang terkumpul akan meningkat.

Penelitian tentang variabel makroekonomi terhadap jumlah penerimaan zakat telah dilakukan oleh beberapa peneliti dan mereka menemukan hasil yang berbeda. Oran (2009) dan Ahmad (2011) menjelaskan dalam hasil penelitiannya bahwa kurs dan harga emas berpengaruh positif terhadap penerimaan zakat, sedangkan variabel inflasi pengaruhnya negatif. Penelitian yang dilakukan oleh Dwitama dan Widiastuti (2016) menjelaskan pengaruh kurs atau nilai tukar terhadap jumlah zakat yang terkumpul adalah positif, sedangkan variabel inflasi berpengaruh negatif. Beik dan Noviyanti (2016) melakukan penelitian faktor variabel makroekonomi terhadap penerimaan zakat, infaq, shadaqah (ZIS). Hasil penelitiannya menunjukkan bahwa inflasi berpengaruh negatif terhadap jumlah penerimaan zakat.

Berdasarkan latar belakang di atas, rumusan dalam penelitian ini adalah untuk mengetahui apakah inflasi, kurs atau nilai tukar dan harga emas berpengaruh terhadap jumlah penerimaan zakat di lembaga badan amil zakat nasional (Baznas) pusat. Sedangkan tujuan dari penelitian ini adalah untuk menguji secara empiris apakah inflasi, kurs atau nilai tukar dan harga emas berpengaruh terhadap jumlah penerimaan zakat di lembaga badan amil zakat nasional (Baznas) pusat.

\section{Inflasi}

Inflasi adalah kenaikan harga secara umum, atau bisa disebut sebagai penurunan daya beli uang. Semakin tinggi kenaikan harga maka semakin menurunkan nilai uang. Ukuran inflasi yang paling banyak digunakan adalah Consumer Price Indeks atau Cost of Living Indeks. Indeks ini berdasarkan pada harga dari satu paket barang yang dipilih dan mewakili pola pengeluaran. Menurut Boediono (1994), Inflasi adalah kecenderungan dari harga-harga untuk naik secara umum dan terus menerus. Ada beberapa komponen yang harus diperhatikan yaitu:

a. Kenaikan harga, yaitu apabila harga suatu komoditas menjadi lebih tinggi dari harga periode sebelumnya.

b. Bersifat umum, yaitu kenaikan harga komoditas secara umum yang dikonsumsi masyarakat bukan merupakan kenaikan suatu komoditas yang tidak menyebabkan harga naik secara umum.

c. Berlangsung terus menerus, kenaikan harga yang bersifat umum belum akan memunculkan inflasi jika terjadi sesaat, misalnya kenaikan harga pada saat lebaran atau tahun baru bukan merupakan inflasi.

Menurut Putong (2002), Inflasi dibedakan menjadi tiga jenis, antara lain:

1. Menurut sifatnya, yaitu rendah, menengah, berat dan tinggi.

2. Menurut penyebabnya, yaitu tarikan permintaan (Demand Pull Inflation) dan 
dorongan biaya (Cost Push Inflation).

3. Menurut asalnya, yaitu

a. Inflasi yang berasal dari dalam negeri (Domestic Inflation) yang timbul karena terjadinya defisit dalam pembiayaan dan belanja negara.

b. Inflasi yang berasal dari luar negeri terjadi karena negara yang menjadi mitra dagang mengalami inflasi yang tinggi.

\section{Kurs atau nilai tukar}

Kurs atau nilai tukar adalah perbandingan antara harga mata uang suatu negara dengan mata uang negara lain. Menurut Triyono (2008), Kurs adalah pertukaran antara dua mata uang yang berbeda yaitu perbandingan nilai atau harga antara kedua mata uang tersebut sehingga bisa dikatakan bahwa nilai tukar rupiah adalah suatu perbandingan antara nilai mata uang suatu negara dengan negara lain. Selain itu nilai tukar mencerminkan keseimbangan permintaan dan penawaran terhadap mata uang dalam negeri maupun mata uang asing. Merosotnya nilai tukar rupiah merefleksikan menurunnya permintaan masyarakat terhadap mata uang rupiah karena menurunnya peran perekonomian nasional atau karena meningkatnya permintaan mata uang asing sebagai alat pembayaran internasional. Begitupun juga sebaliknya, semakin menguatnya kurs rupiah berarti menggambarkan kinerja di pasar uang semakin baik. Sebagai dampak meningkatnya laju inflasi maka nilai tukar domestik semakin melemah terhadap mata uang asing sehingga mengakibatkan menurunnya kinerja suatu perusahaan dan investasi di pasar modal menjadi berkurang.

Sedangkan menurut Adiningsih (1998), nilai tukar rupiah adalah harga rupiah terhadap mata uang negara lain. Jadi, nilai tukar rupiah merupakan nilai dari satu mata rupiah yang ditranslasikan ke dalam mata uang negara lain. Misalnya nilai tukar rupiah terhadap dolar Amerika, nilai tukar rupiah terhadap Yen, dan lain sebagainya. Kurs inilah sebagai salah satu indikator yang mempengaruhi aktivitas di pasar saham maupun pasar uang karena investor cenderung akan berhati-hati untuk melakukan investasi.

\section{Harga Emas}

Sudah sejak lama emas telah mendapat tempat yang sangat istimewa dalam kehidupan manusia. Logam mulia ini memiliki sejumlah keistimewaan yang tidak dimiliki oleh logam-logam lainnya. Oleh sebab itu, sejak lama logam mulia ini telah menjadi patokan bagi perdagangan antar komunitas, antar wilayah, dan kemudian antar Negara. Karena sangat istimewanya emas, Ibnu Khaldun (2000) mengatakan bahwa Allah SWT telah menciptakan emas dan perak sebagai alat pengukur nilai (measure of value) bagi segala sesuatu. Amin (2007) dalam Satanic Finance: True Conspiracy menuliskan, "Dalam sejarah manusia, tak lebih dari 90.000 ton emas yang ditambang dari perut bumi. Sementara perak dan tembaga untuk memenuhi transaksi dengan nilai yang lebih rendah dari emas".

Archimedes pada abad 300 SM juga telah membuktikan bahwa emas bisa dideteksi tanpa merusak dengan hanya menggunakan alat bantu air tawar biasa. Selain itu emas juga tidak dapat diubah dengan bahan kimia lainnya (indestructible), tidak bisa terpengaruh oleh air, udara, dan kelembaban dan tidak bisa berkarat (Amin, 2007). Iron and Steel Institute, sebuah lembaga ilmiah yang melakukan pengkajian terhadap banyak logam termasuk emas yang bermarkas di Washington DC, menyatakan bahwa produksi 
baja di Amerika serikat sejak tahun 1995 mencapai 10.500 ton pertahunnya. Sementara penambangan emas sedunia dari tahun ke tahun hanya mengalami kenaikan dua persen. Dalam satu tahun, indutri tambang emas seluruh dunia hanya sanggup menghasilkan sekitar 2000 ton emas. Dibandingkan dengan total produksi baja, kelangkaan emas ini merupakan salah satu keistimewaannya. Disebabkan kelangkaan dan keistimewaannya, emas dan perak telah terbukti sepanjang sejarah manusia sebagai alat tukar yang nilainya sangat stabil.(www.eramuslim.com)

\section{Zakat}

Zakat secara harfiah berarti berkah, bersih, baik dan meningkat. Zakat juga berarti pembersihan diri yang didapatkan setelah pelaksanaan kewajiban membayar zakat. Oleh karena itu, harta benda yang di keluarkan untuk zakat akan membantu mensucikan jiwa manusia dari sifat mementingkan diri sendiri, kikir dan cinta harta. Dalam istilah fikih, zakat adalah sejumlah harta yang dikeluarkan dari jenis harta tertentu yang di serahkan kepada orang-orang yang berhak menerimanya dengan syarat yang telah di tentukan. sebagaimana firman Allah SWT:

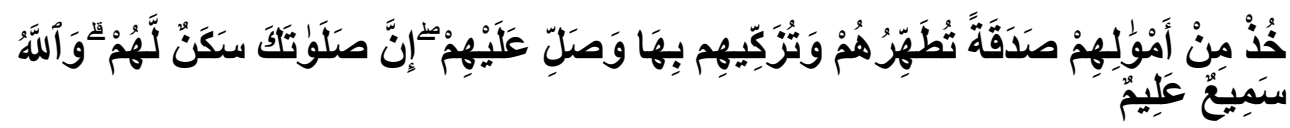

Artinya: "Ambillah zakat dari sebagian harta mereka, dengan zakat itu kamu membersihkan dan mensucikan mereka dan berdoalah untuk mereka. Sesungguhnya doa kamu itu (menjadi) ketentraman jiwa bagi mereka, dan Allah maha mendengar lagi maha mengetahui”. (Q.S At-Taubah : 103)

Al-Zuhayly (2008) menjelaskan syarat wajib zakat adalah sebagai berikut:

1. Merdeka, dimana zakat tidak wajib atas hamba sahaya/budak karna hamba sahaya tidak mempunyai hak milik.

2. Islam.

3. Baliqh dan berakal, dimana zakat wajib dikeluarkan oleh orang yang sudah baligh dan berakal.

4. Harta yang dikeluarkan adalah harta yang wajib dizakati. Harta yang dizakati disyaratkan produktif, yakni berkembang artinya disipakan untuk dikembangkan, baik melalui perdagangan maupun berupa binatang yang diternakkan.

5. Harta yang dizakati telah mencapai nisab atau senilai dengannya.

6. Harta yang dizakati adalah milik sendiri.

7. Kepemilikan harta telah mencapai setahun.

8. Harta tersebut bukan harta hasil hutang.

Lembaga amil zakat merupakan organisasi yang cenderung bersifat nirlaba, artinya lembaga amil adalah institusi yang fungsinya untuk menyalurkan zakatnya guna kemaslahatan ekonomi umat (Jaelani, 2008). Kegiatannya antara lain adalah mengumpulkan, mendistribusikan, dan mendayagunakan dana zakat dari masyarakat. Menurut Arif (2012), keuntungan jika zakat dikelola oleh sebuah lembaga publik profesional dengan memadukan unsur pemerintah, swasta, dan kelompok masyarakat antara lain:

1. Para pembayar zakat akan lebih disiplin dalam menunaikan kewajibannya dan 
fakir miskin lebih terjamin haknya.

2. Perasaan fakir miskin terjaga, tidak merasa seperti peminta-minta.

3. Distribusi dana zakat akan menjadi lebih tertib, teratur, dan berdaya guna dalam mengembangkan potensi ekonomi kaum fakir miskin.

4. Peruntukan dana zakat bagi kepentingan umum dapat disalurkan dengan baik, karena pihak pemerintah lebih mengetahui sasaran pemanfaatannya.

\section{Hubungan Antara Indikator Makroekonomi Terhadap Besarnya Jumlah Zakat Yang Terkumpul}

Berdasarkan hasil penelitian Rohani (2016), terdapat hubungan yang siginifikan dan positif antara inflasi dengan tingkat kemiskinan. Pada dasarnya inflasi merupakan suatu keadaan dimana terdapat kenaikan harga secara umum dan terus menerus yang mengakibatkan nilai mata uang turun. Pemahaman terbesar tentang inflasi adalah inflasi mengganggu daya beli riil masyarakat, sehingga membuat masyarakat lebih miskin. Kemiskinan merupakan suatu kondisi dimana orang tidak mempunyai cukup pendapatan yang dapat digunakan untuk memenuhi kebutuhan minimum. Artinya, inflasi mengakibatkan harga terhadap barang-barang menjadi naik secara menyeluruh dan terus-menerus yang mengakibatkan turunnya nilai mata uang sehingga mengakibatkan konsumsi masyarakat turun.

Hal ini berarti bahwa dengan penurunan daya beli maka akan berakibat pada naiknya tingkat kemiskinan. Pola konsumsi yang turun bukan diakibatkan minimnya jumlah produksi barang-barang, tetapi karena daya untuk membeli barang tidak ada sehingga sangat sulit untuk memenuhi kebutuhan minimum. Kondisi ini mengakibatkan orang yang tadinya berada pada garis mendekati miskin menjadi miskin dengan adanya inflasi. Hal ini tentunya akan mengakibatkan bertambahnya orang yang berhak menerima zakat atau mustahiq dan menurunnya jumlah muzakki karena bertambahnya jumlah orang yang hidup di bawah garis kemiskinan sehingga besarnya nilai zakat yang terkumpulpun akan berkurang.

Melemahnya nilai tukar rupiah terhadap mata uang asing terutama dolar Amerika akan mendorong naiknya tingkat harga. Dengan banyaknya bahan baku yang berasal dari impor dan dinilai dalam dolar, menyebabkan harga bahan baku tersebut dalam rupiah menjadi meningkat. Kenaikan harga bahan baku akan meningkatkan harga barang jadi, karena biaya pembuatan barang jadi turut meningkat. Di sisi lain, meningkatnya harga bahan baku menyebabkan banyak produsen tidak mampu berproduksi dikarenakan meningkatnya biaya produksi, sehingga persediaan barang menjadi berkurang, akibatnya barang menjadi langka di pasaran dan harga barang meningkat. Dengan meningkatnya harga barang karena kelangkaan di pasaran menyebabkan turunnya daya beli masyarakat sehingga mengakibatkan inflasi. Inflasi yang seperti ini biasa disebut sebagai cost push inflation, yaitu inflasi desakan biaya karena meningkatnya harga bahan baku sehingga suplai barang berkurang, akibatnya harga barang menjadi naik. Menurunnya daya beli masyarakat akan membuat mereka lebih mengutamakan dan memprioritaskan kebutuhan pokok terlebih dahulu dari pada yang lain sehingga jumlah zakat yang dikeluarkan masyarakat akan menjadi berkurang.

Jika harga emas naik, maka jumlah penghasilan yang dibutuhkan masyarakat untuk mencapai nisab zakat akan bertambah. Hal ini dikarenakan pendapatan masyarakat dalam rupiah. Sehingga, ketika pendapatan masyarakat dikonversi ke dalam harga emas, 
maka pendapatan masyarakat menurun dibandingkan harga emas. Akibatnya, jumlah orang yang berzakat menurun karena jumlah masyarakat yang belum mencapai nisab bertambah. Hal ini tentunya akan menurunkan besarnya jumlah zakat. Untuk jumlah penerima zakat mungkin akan bertambah atau berkurang. Ini karena menurunnya jumlah orang yang pendapatannya mencapai nisab zakat belum tentu akan menjadikan mereka miskin atau berhak menerima zakat. Karena kenaikan harga barang-barang yang menyebabkan menurunya daya beli masyarakat tidak secara langsung dipengaruhi oleh kenaikan harga emas.

\section{Kerangka penelitian}

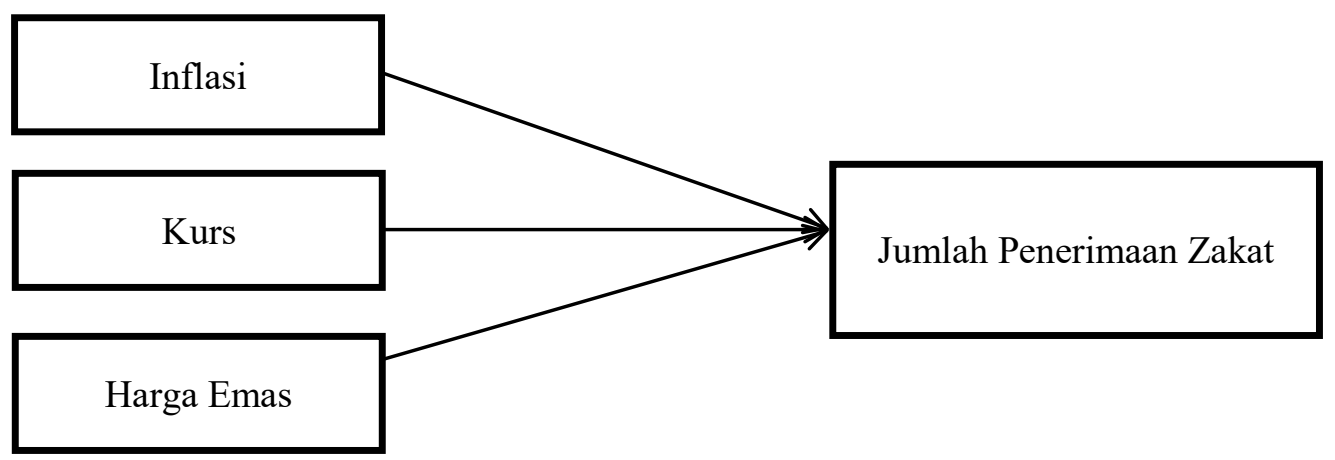

Gambar 1. Kerangka penelitian

\section{PENGEMBANGAN HIPOTESIS}

\section{Pengaruh Inflasi Terhadap Jumlah Penerimaan Zakat}

Menurut Beik dan Novianti (2016) serta Ahmad (2011), kenaikan tingkat inflasi menunjukkan adanya kenaikan tingkat harga barang dan jasa secara umum, termasuk harga beras sebagai penentu besarnya nisab zakat. Kenaikan harga beras akan meningkatkan besarnya batas nisab zakat yang harus dicapai oleh muzakki. Jika pendapatan tetap, atau kenaikannya lebih rendah dari kenaikan inflasi, kemampuan muzakki untuk mencapai batas nisab akan menurun. Hal ini akan mengakibatkan terjadinya penurunan jumlah muzakki sehingga menurunkan jumlah penerimaan zakat. Selain itu, kenaikan inflasi akan menurunkan kemampuan daya beli masyarakat. Penurunan daya beli masyarakat akan mengakibatkan seseorang harus membayar lebih untuk mendapatkan jumlah barang dan jasa yang sama sehingga akan berakibat pada alokasi dana untuk zakat, infak dan sedekah menjadi berkurang karena terjadi peningkatan alokasi dana untuk memenuhi kebutuhan. Oleh karena itu, kenaikan inflasi akan menurunkan jumlah penerimaan zakat pada lembaga amil zakat.

\section{H1: Inflasi berpengaruh negatif terhadap jumlah penerimaan zakat}

\section{Pengaruh Kurs Terhadap Jumlah Penerimaan Zakat}

Menurut Dwitama dan Widiastuti (2016) serta Ahmad (2011), meningkatnya nilai tukar dolar terhadap rupiah bukan hanya membawa dampak buruk, tetapi juga membawa dampak baik. Meningkatnya nilai tukar dolar terhadap rupiah, akan meningkatkan pendapatan masyarakat yang mempunyai penghasilan dalam dolar. Bagi mere- 
ka, naiknya dolar terhadap rupiah merupakan berkah, karena penghasilan yang diterima oleh mereka akan lebih banyak dibanding sebelumnya sehingga hal ini akan berdampak kepada meningkatnya jumlah zakat yang mereka keluarkan karena perhitungan zakat terhadap penghasilan mereka juga meningkat.

\section{H2: Kurs berpengaruh positif terhadap jumlah penerimaan zakat}

\section{Pengaruh Harga Emas Terhadap Jumlah Penerimaan Zakat}

Menurut Ahmad (2011), kenaikan harga emas dalam dolar Amerika akan menyebabkan naiknya nilai nisab dalam rupiah. Hal ini tentunya berlaku bagi orangorang yang menyimpan emas dalam harta kekayaannya, sehingga meningkatnya harga emas akan meningkatkan penghasilan mereka dalam rupiah. Akibatnya jumlah zakat yang harus dikeluarkan akan lebih besar dan pada akhirnya jumlah zakat yang terkumpul akan meningkat.

\section{H3: Harga Emas berpengaruh positif terhadap jumlah penerimaan zakat}

\section{METODOLOGI PENELITIAN}

\section{Data dan Sampel}

Jenis data yang digunakan dalam penelitian ini adalah data sekunder. Data inflasi dan kurs rupiah terhadap dolar Amerika diperoleh dari Bank Indonesia (www.bi.go.id), sedangkan harga emas diperoleh dari Bloomberg (www.bloomberg.com). Untuk data zakat berasal dari lembaga amil zakat badan amil zakat nasional pusat (Baznas) (www. baznas.go.id).

Teknik pengambilan sampel dilakukan secara subyektif oleh penulis berkaitan dengan penelitian yang dilakukan tanpa mempertimbangkan probabilitas terpilihnya data tersebut (non probability). Dari data populasi, diambil sampel yang meliputi data bulanan mulai dari tahun 2012 sampai 2016.

\section{Model dan Teknik Analisis Data}

Metode analisis yang digunakan dalam penelitian ini adalah metode analisis regresi linier berganda dengan persamaan kuadrat terkecil (Ordinary Least Square). Analisis ini digunakan untuk mengetahui seberapa besar pengaruh dari beberapa variabel independen terhadap variabel dependen. Sebelum melakukan analisis regresi linier berganda, terlebih dahulu melakukan uji asumsi klasik. Uji asumsi klasik yang digunakan terdiri dari uji normalitas, uji autokorelasi, uji multikolinieritas dan uji heteroskedastisitas. Berikut ini adalah model dasar penelitian:

$\mathrm{Y}=\alpha+\beta 1 \mathrm{X} 1+\beta 2 \mathrm{X} 2+\beta 3 \mathrm{X3}+\varepsilon$

Dimana:

$\mathrm{Y}=$ Jumlah penerimaan zakat

$\mathrm{X} 1=$ Inflasi

$\mathrm{X} 2=$ Kurs (nilai tukar rupiah terhadap dolar amerika)

X3 = Harga emas

$\mathrm{E}=$ Error 


\section{HASIL PENELITIAN DAN PEMBAHASAN}

\section{Statistik Deskriptif}

Tabel 1.Hasil Analisis Statistik Deskriptif

\begin{tabular}{lrrrr}
\hline & LOG ZAKAT & \multicolumn{1}{l}{ INFLASI } & \multicolumn{1}{l}{ KURS } & \multicolumn{1}{l}{ EMAS } \\
\hline Mean & 21.76021 & 0.055153 & 11681.95 & 541898.3 \\
Median & 21.55986 & 0.048600 & 11913.86 & 539600.0 \\
Maximum & 22.64033 & 0.087900 & 14396.10 & 602000.0 \\
Minimum & 21.02596 & 0.027900 & 9025.760 & 435500.0 \\
Std. Dev. & 0.454163 & 0.017702 & 1660.449 & 28203.53 \\
Skewness & 0.325706 & 0.312825 & -0.251998 & -0.459344 \\
Kurtosis & 1.653680 & 1.797079 & 1.588886 & 5.331707 \\
Jarque-Bera & 5.592286 & 4.596142 & 5.613134 & 15.70211 \\
Probability & 0.061045 & 0.100452 & 0.060412 & 0.000389 \\
Sum & 1305.613 & 3.309200 & 700916.9 & 32513900 \\
Sum Sq.Dev. & 12.16958 & 0.018488 & $1.63 \mathrm{E}+08$ & $4.69 \mathrm{E}+10$ \\
Observations & 60 & 60 & 60 & 60 \\
\hline
\end{tabular}

Sumber: Data yang diolah

Berdasarkan hasil analisa statistik deskriptif di atas menunjukkan bahwa besarnya jumlah penerimaan zakat berkisar antara 21.02596 sampai dengan 22.64033, dengan rata-rata sebesar 21.76021 dan standar deviasi sebesar 0.45416 . Untuk nilai inflasi berkisar antara 0.02790 sampai dengan 0.08790 , dengan rata-rata sebesar 0.05515 dan standar deviasi sebesar 0.01770 . Untuk nilai kurs berkisar antara 9025.760 sampai dengan 14396.10, dengan rata-rata sebesar 11681.95 dan standar deviasi sebesar 1660.449. Sedangkan nilai harga emas berkisar antara 435500 sampai dengan 602000 , dengan rata-rata sebesar 541898.3 dan standar deviasi sebesar 28203.53 .

\section{Uji Asumsi Klasik}

Berdasarkan hasil penelitian maka diperoleh hasil uji asumsi klasik sebagai berikut ini:

\section{Uji Normalitas}

Hasil uji normalitas dapat dilihat melalui tabel berikut: 


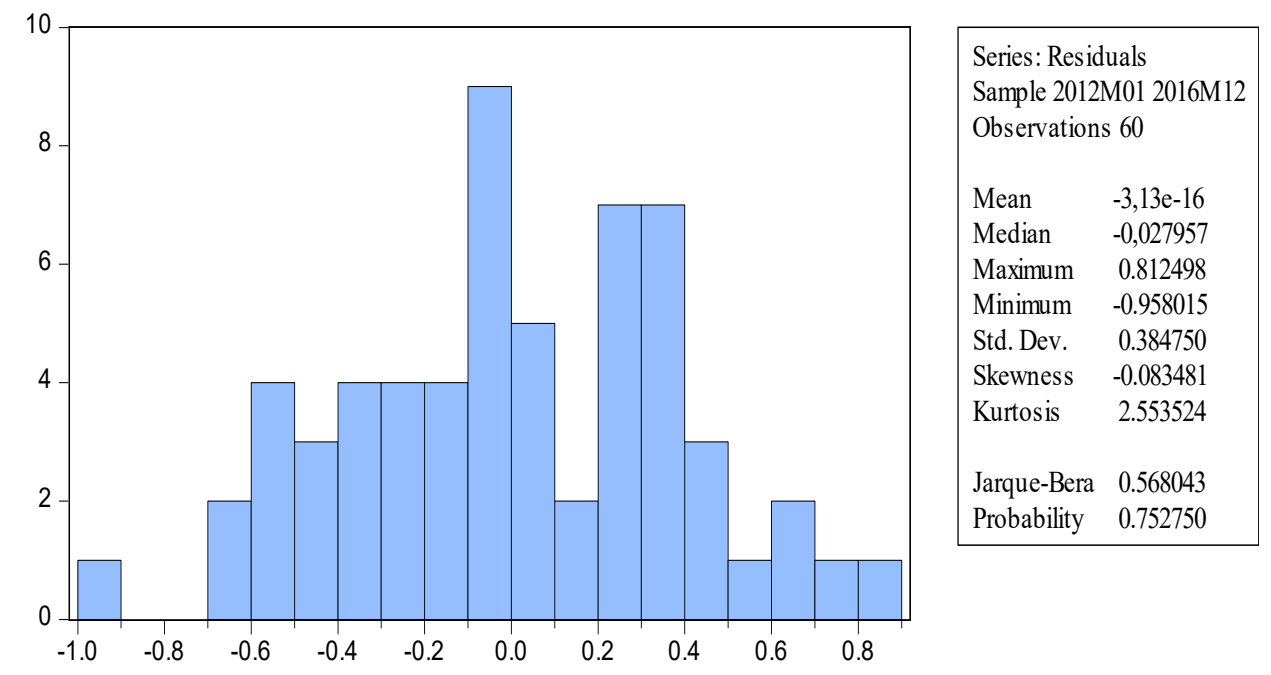

Sumber: Data yang diolah

Gambar 2.Uji Normalitas

Gambar atas menunjukkan bahwa nilai probabilitas Jarque-Bera hitung sebesar $0,7527>0,05$ sehingga dapat disimpulkan bahwa model regresi berdistribusi normal.

\section{Uji Autokorelasi}

Hasil uji autokorelasi bisa di lihat melalui tabel berkut:

Tabel 2.Uji Autokorelasi Breusch-Godfrey Serial Correlation LM Test

\begin{tabular}{llll}
\hline F-statistic & 0.83209 & Prob. F $(2,54)$ & 0.4406 \\
\hline Obs*R-squared & 1.793807 & Prob. Chi-Square(2) & 0.4078 \\
\hline
\end{tabular}
(Sumber: Data yang diolah)

Tabel di atas menunjukkan bahwa nilai probabilitas F hitung $(2,54)$ sebesar 0,4406 lebih besar dari tingkat alpha 0,05 sehingga model regresi tidak terjadi autokorelasi.

\section{Uji Multikolinieritas}

Hasil uji multikolinieritas bisa di lihat melalui tabel berikut

Tabel 3.Uji Multikolinieritas

\begin{tabular}{lccc}
\hline & Coefficient & Uncentered & Centered \\
\hline \multicolumn{1}{c}{ Variable } & Variance & VIF & VIF \\
\hline $\mathrm{C}$ & 1.583155 & 609.0518 & NA \\
INFLASI & 12.01239 & 15.48133 & 1.423974 \\
KURS & $1.10 \mathrm{E}-09$ & 59.14136 & 1.152045 \\
EMAS & $5.16 \mathrm{E}-12$ & 584.8489 & 1.553676 \\
\hline
\end{tabular}

(Sumber: Data yang diolah)

Tabel di atas menunjukkan bahwa nilai Centered VIF tidak lebih besar dari 10 
maka dapat dikatakan tidak terjadi multikolinieritas pada variabel bebas.

\section{Uji Heteroskedastisitas}

Hasil uji heterokedastisitas bisa dilihat melalui tabel berikut:

Tabel 4.Uji Heteroskedastisitas

\begin{tabular}{lrll}
\hline F-statistic & 1.13730 & Prob. F(9,50) & 0.3551 \\
\hline Obs*R-squared & 10.19565 & Prob. Chi-Square(9) & 0.3349 \\
\hline Scaled explained SS & 6.898845 & Prob. Chi-Square(9) & 0.6477 \\
\hline
\end{tabular}

Sumber: Data yang diolah

Uji heteroskedastisitas dalam penelitian ini menggunakan uji White, dimana nilai probabilitas $\mathrm{F}$ hitung sebesar 0,3551 lebih besar dari tingkat alpha 0,05 sehingga model regresi tidak terjadi heteroskedastisitas.

\section{Analisis regresi linear berganda}

Analisis regresi linier berganda merupakan model analisis yang berfungsi untuk mengetahui pengaruh variabel independen terhadap variabel dependen.

Tabel 5. Analisis Regresi Linear Berganda

\begin{tabular}{lrlrr}
\hline \multicolumn{1}{c}{ Variable } & \multicolumn{1}{c}{ Coefficient } & \multicolumn{1}{l}{ Std. Error } & \multicolumn{1}{c}{ t-Statistic } & \multicolumn{1}{c}{ Prob. } \\
\hline C & $2,256,214$ & $1,258,235$ & $1,793,158$ & 0,0000 \\
INFLASI & $-7,089,211$ & 346,589 & $-2,045,423$ & 0,0455 \\
KURS & 0,000151 & $3,32 \mathrm{E}-05$ & 455,371 & 0,0000 \\
EMAS & $-4,02 \mathrm{E}-06$ & $2,27 \mathrm{E}-06$ & $-1,769,531$ & 0,0822 \\
R-squared & 0.282316 & Mean dependent var & 21.76021 \\
Adjusted R-squared & 0.243869 & S.D. dependent var & 0.454163 \\
S.E. of regression & 0.394921 & Akaike info criterion & 1.044079 \\
Sum squared resid & 8.733907 & Schwarz criterion & 1.183702 \\
Log likelihood & -27.32236 & Hannan-Quinn criter. & 1.098693 \\
F-statistic & 7.342938 & Durbin-Watson stat & 1.656578 \\
Prob(F-statistic) & 0.00031 & & \\
\hline Strat & & &
\end{tabular}

Sumber: Data yang diolah

Jumlah Penerimaan Zakat $=2256214-(7.089211 \times$ Inflasi $)+(0.000151 \times$ Kurs $)-$ (4.02E-06 x Harga Emas) $+\varepsilon$

\section{PEMBAHASAN}

\section{Uji Signifikansi Parameter Individual (Uji t)}

\section{Pengaruh inflasi terhadap jumlah penerimaan zakat}

Dari hasil pengujian regresi diatas dapat terlihat bahwa nilai koefisien regresi variabel inflasi adalah -7,0892 dengan nilai t hitung sebesar -2,045 dan tingkat signifikansi sebesar 0,0455. Nilai signifikansi tersebut lebih kecil dari 0,05 atau $\mathrm{Sig} \mathrm{t}=0,040<0,05$. 
Hal ini menunjukkan bahwa pengaruh inflasi terhadap jumlah penerimaan zakat adalah negatif dan signifikan. Hal ini sesuai dengan hasil penelitian Beik dan Noviyanti (2016), Fitriah, Asmara, dan Lubis (2015) serta Ahmad (2011) yang mengatakan bahwa kenaikan tingkat inflasi menunjukkan adanya kenaikan tingkat harga barang dan jasa secara umum, termasuk harga beras sebagai penentu besarnya nisab zakat. Kenaikan harga beras akan meningkatkan besarnya batas nisab zakat yang harus dicapai oleh muzakki. Jika pendapatan tetap, atau kenaikannya lebih rendah dari kenaikan inflasi, kemampuan muzakki untuk mencapai batas nisab akan menurun. Hal ini akan mengakibatkan terjadinya penurunan jumlah muzakki sehingga menurunkan jumlah penerimaan zakat.

Selain itu, kenaikan inflasi akan menurunkan kemampuan daya beli masyarakat. Penurunan daya beli masyarakat akan mengakibatkan seseorang harus membayar lebih untuk mendapatkan jumlah barang dan jasa yang sama sehingga akan berakibat pada alokasi dana untuk zakat menjadi berkurang karena terjadi peningkatan alokasi dana untuk memenuhi kebutuhan. Oleh karena itu, kenaikan inflasi akan menurunkan jumlah penerimaan zakat. Selain itu, inflasi lebih cenderung berpengaruh terhadap jumlah penduduk yang berada di bawah garis kemiskinan. Hal ini sejalan dengan penelitian Fatma (2005) yang menunjukkan bahwa inflasi dan pengangguran berpengaruh signifikan terhadap pendapatan dan pengeluaran masyarakat miskin. Inflasi merupakan permasalahan masyarakat modern yang timbul karena beberapa sebab, antara lain konsumsi masyarakat secara berlebih. Semakin tinggi inflasi maka tingkat kemiskinan akan semakin besar sehingga berdampak pada semakin meningkatnya orang yang berhak menerima zakat atau mustahiq dan menurunnya jumlah orang yang mampu mengeluarkan zakat atau muzakki karena bertambahnya jumlah orang yang yang berada di bawah garis kemiskinan.

\section{Pengaruh kurs atau nilai tukar terhadap jumlah penerimaan zakat}

Dari hasil pengujian regresi diatas dapat terlihat bahwa nilai koefisien regresi variabel kurs adalah 0,0001 dengan nilai t hitung sebesar 4,553 dan tingkat signifikansi sebesar 0,0000. Nilai signifikansi tersebut lebih kecil dari 0,05 atau Sig t $=0,0000<$ 0,05 . Hal ini berarti bahwa pengaruh kurs atau nilai tukar terhadap jumlah penerimaan zakat adalah positif dan signifikan. Penelitian ini sesuai dengan hasil penelitian Dwitama dan Widiastuti (2016) serta penelitian Ahmad (2011) yang menyatakan bahwa meningkatnya nilai tukar dolar terhadap rupiah bukan hanya membawa dampak buruk, tetapi juga membawa dampak baik. Meningkatnya nilai tukar dolar terhadap rupiah, akan meningkatkan pendapatan masyarakat yang mempunyai penghasilan dalam dolar, seperti eksportir. Bagi mereka, naiknya dolar terhadap rupiah merupakan berkah, karena penghasilan yang diterima oleh mereka akan menjadi berlipat ganda dibanding sebelumnya. Hal ini akan berdampak kepada meningkatnya jumlah zakat yang mereka keluarkan karena perhitungan zakat terhadap penghasilan mereka juga meningkat. Hal ini merupakan salah satu penyebab nilai tukar rupiah tidak mempunyai hubungan yang signifikan terhadap jumlah zakat. Melemahnya nilai tukar rupiah terhadap dolar tidak lepas dari sistem nilai tukar mengambang (Free Floating Exchange Rate System) yang diterapkan dalam perekonomian Indonesia. Sistem Ekonomi Islam memandang seharusnya sistem nilai tukar yang diterapkan adalah sistem nilai tukar tetap, dimana kestabilan mudah tercapai dengan intervensi pemerintah untuk kesejahteraan umat. 


\section{Pengaruh harga emas terhadap jumlah penerimaan zakat}

Dari hasil pengujian regresi diatas dapat terlihat bahwa nilai koefisien regresi variabel harga emas adalah -4,02E-06 dengan nilai t hitung sebesar -1,769 dan tingkat signifikansi sebesar 0,082 . Hal ini menunjukkan bahwa pengaruh harga emas terhadap jumlah penerimaan zakat adalah negatif dan tidak signifikan. Kenaikan harga emas biasanya dipengaruhi oleh tingginya tingkat inflasi yang mengakibatkan kenaikan tingkat barang dan lainnya, hal ini akan membuat seseorang yang mempunyai pendapatan tetap (tidak berubah) akan menggunakan pendapatan mereka untuk kebutuhan yang lebih penting dan akhirnya mengurangi jatah untuk membayar zakat sehingga penerimaan jumlah zakat akan menurun. Hasil Penelitian ini berbeda dengan hasil penelitian Ahmad (2011) yang menyatakan bahwa harga emas berpengaruh positif terhadap jumlah penerimaan zakat. Kenaikan harga emas dalam dolar Amerika akan menyebabkan naiknya nilai nisab dalam rupiah. Hal ini tentunya berlaku bagi orang-orang yang menyimpan emas dalam harta kekayaannya, sehingga meningkatnya harga emas akan meningkatkan penghasilan mereka dalam rupiah. Akibatnya jumlah zakat yang harus dikeluarkan akan lebih besar dan pada akhirnya jumlah zakat yang terkumpul akan meningkat.

\section{Uji Signifikansi Parameter Keseluruhan Model (Uji F)}

Dari hasil pengujian regresi diatas dapat terlihat nilai probabilitas $\mathrm{F}$ sebesar 0,00031 lebih kecil dari tingkat signifikansi 0,05 sehingga dapat disimpulkan bahwa model regresi yang di estimasi layak digunakan untuk menjelaskan pengaruh inflasi, kurs dan harga emas terhadap jumlah penerimaan zakat.

\section{Uji Koefisien Determinasi (R2)}

Tabel 6.Uji Koefisien Determinasi

Model Summary

\begin{tabular}{llll}
\hline Model & R-Square & Adjusted R Square & Std. Error of Regression \\
\hline 1 & 0,2823 & 0,2438 & 0,3949 \\
\hline
\end{tabular}

Dependent variable : Log (Zakat)

Sumber: Data yang diolah

Nilai adjusted R dalam penelitian ini sebesar 0.2438 atau $24,38 \%$. Hal ini berarti variabel jumlah penerimaan zakat dapat dipengaruhi oleh inflasi, kurs dan harga emas sebesar $24,38 \%$, sedangkan sisanya sebesar 75,62 \% di jelaskan oleh variabel lain di luar penelitian.

\section{KESIMPULAN}

Berdasarkan hasil penelitian mengenai pengaruh variabel makroekonomi terhadap jumlah penerimaan zakat di badan amil zakat nasional (Baznas) tahun 2012 - 2016 maka dapat disimpulkan bahwa Inflasi berpengaruh negatif dan signifikan terhadap jumlah penerimaan zakat. Kenaikan inflasi akan mengakibatkan kemampuan orang dalam membayar zakat menjadi turun sehingga jumlah penerimaan zakat akan berkurang. Sedangkan Kurs atau nilai tukar berpengaruh positif dan signifikan terhadap 
jumlah penerimaan zakat. Kenaikan kurs dolar terhadap rupiah bukan hanya membawa dampak buruk, tetapi juga membawa dampak baik bagi seseorang yang mempunyai penghasilan dalam bentuk dolar, hal ini akan berpengaruh terhadap meningkatnya jumlah zakat yang mereka keluarkan karena perhitungan zakat terhadap penghasilan mereka juga meningkat. Sedangkan untuk variabel harga emas berpengaruh secara negatif dan tidak signifikan terhadap jumlah penerimaan zakat. Kenaikan harga emas biasanya dipengaruhi oleh tingginya tingkat inflasi yang mengakibatkan kenaikan tingkat barang dan lainnya, hal ini akan membuat seseorang yang mempunyai pendapatan tetap akan menggunakan pendapatan mereka untuk kebutuhan yang lebih penting dan akhirnya mengurangi jatah untuk membayar zakat sehingga penerimaan jumlah zakat akan menurun. Untuk nilai adjusted $\mathrm{R}$ squared dalam penelitian ini sebesar 0.2438 atau $24,38 \%$, hal ini menunjukkan bahwa variabel independen yaitu inflasi, kurs atau nilai tukar dan harga emas hanya mampu menjelaskan pengaruh variabel dependen sebesar 24,38\% sedangkan sisanya sebesar 75,62 \% dijelaskan oleh variabel lain di luar penelitian. Selain itu dari hasil penelitian ini diharapkan mampu memberikan manfaat bagi pemangku kebijakan untuk lebih berhati-hati dalam menyikapi perubahan ekonomi global terutama indikator makroekonomi agar tidak mempengaruhi seseorang untuk membayar zakat.

\section{SARAN}

Beberapa saran yang dapat peneliti sampaikan berdasarkan analisis yang telah dilakukan adalah Penelitian ini hanya menggunakan periode waktu 5 tahun yaitu mulai dari 2012 - 2016, sebaiknya untuk penelitian berikutnya mencoba menguji dengan menambahkan sampel periode pengamatan yang lebih banyak guna mendapatkan hasil yang lebih baik.Penelitian selanjutnya hendaknya menambahkan beberapa variabel makroekonomi seperti indeks produksi industri (IPI), jumlah uang beredar (M2), suku bunga Bank Indonesia (BI Rate).Ada variabel yang diketahui pengaruhnya kurang signifikan, kemungkinan pemilihan periode waktu nya kurang banyak.

\section{DAFTAR PUSTAKA}

Abimanyu, Y. (2004). Memahami Kurs Valuta Asing. Jakarta. Lembaga Penerbit Fakultas Ekonomi Universitas Indonesia.

Adiningsih, S. (1998). Perangkat Analisis dan Teknik Analisisis Investasi di Pasar Modal Indonesia. Jakarta: P.T. Bursa Efek Jakarta.

Alexander, G. J., Sharpe, W. F., \& Bailey, J. V. (2000). Fundamentals of Investment. $3^{\text {rd }}$ ed. New Jersey: Prentice Hall, Inc.

Amin, A. R. (2007). Satanic Finance: True Conspiracy. Jakarta: Celestial Publishing.

Ahmad, Z. M. (2011). Pengaruh Indikator Makroekonomi Terhadap Besarnya Jumlah Zakat yang Terkumpul di Lembaga Amil Zakat Dompet Dhuafa Republika Tahun 1993-2009. Tesis tidak diterbitkan. Jakarta: Universitas Indonesia.

Arif, S. (2012). Redistribusi Hak Orang Miskin Melalui Zakat Produktif. Jurnal Ekonomi Islam, III, 1(6): 39-59.

Al-Zuhayly, W. (2008). Zakat: Kajian Berbagai Mazhab. Bandung: Remaja Rosdakarya.

Bariadi, L., Zen, M., \& Hudri. (2005). Zakat dan Wirausaha. Jakarta: Centre for Entrepreneurship Development.

Beik, I. S., \& Noviyanti. (2016, Oktober 27). Pengaruh Variabel Makro Terhadap Penerimaan ZIS 
Dompet Dhuafa. Republika. Diakses dari www.republika.co.id.

Dwitama, R. B., \& Widiastuti. (2016). Pengaruh Indikator Makroekonomi: Infasi dan Nilai Tukar Rupiah Terhadap Jumlah Zakat Terkumpul di Lembaga Amil Zakat Dompet Dhuafa Periode 1997-2013. Jurnal Ekonomi Syariah Teori dan Terapan, 3 (7): 584-599

Boediono. (1994). Ekonomi Moneter. Seri Sinopsis Pengantar Ilmu Ekonomi No. 2.

Yogyakarta. BPFE.

Fabozzi, F. J., \& Franco, A. (1996). Handbook of Emerging Fixed Income \& Currency Market. Frank J. Fabozzi Associates New Hope, Pennsylvania.

Fatma, F. S. (2005). Pengaruh Inflasi dan Pengangguran Terhadap Kemiskinan di Indonesia. Tesis tidak diterbitkan. Jakarta: Universitas Indonesia.

Fitriah, S. N.,Asmara,A., \& Lubis, D. (2015, Juli 23). Dampak Makroekonomi Pada Penghimpunan ZIS Badan Amil Zakat Nasional Pusat. Republika. Diakses dari www.republika.co.id

Khaldun, I. (2000). Muqaddimah Ibnu Khaldun. Terjemahan oleh Ahmadie Thoha. Cet IV. Jakarta: Pustaka Firdaus.

Putong, I. (2002). Pengantar ekonomi mikro dan makro, Jakarta: Ghalia Indonesia

Jaelani, A. (2008). Pengaruh Kualitas Pelayanan dan Social Marketing Lembaga Amil Zakat

(LAZ) Terhadap Keputusan Berzakat Muzakki. Tesis tidak diterbitkan. Jakarta: Universitas Indonesia.

Mankiw, N. G. (2007). Principles of Economics. Fourth Edition. Ohio: Thomson. South-Western. Oei, I. (2009). Kiat Investasi Valas, Emas, Saham. Jakarta: Gramedia Pustaka Utama

Oran, A. F. (2009). Zakat Funds and Wealth Creation. International Association For Islamic Economics Review Of Islamic Economics, 13 (1).

Rohani. (2016). Pengaruh Pertumbuhan Penduduk, Pertumbuhan Ekonomi, Pengangguran, dan Inflasi Terhadap Tingkat Kemiskinan di Provinsi Sulawesi Selatan. Makassar: Skripsi. Fakultas Ekonomi dan Bisnis Islam. UIN Alaudin Makassar.

Triyono. (2008). Analisis Perubahan Kurs Rupiah Terhadap Dolar Amerika. Jurnal Ekonomi Pembangunan, 9(2): 156 - 167.

\section{Internet:}

www.bi.go.id, www.bloomberg.com www.baznas.go.id www.eramuslim.com 